The McCarron Lectures*

\section{Lecture 2: The Presocratics}

\author{
Gary McCarron
}

Simon Fraser University
Scholarly and Research

Communication

VOLUME 12 / ISSUE 1 / 2021

\begin{abstract}
The lectures in this series open with general comments about rhetoric, rhetorical questions, moral problems, and issues relating to the connections between emotions and persuasion. Even though persuasion may be a foundation point of rhetoric, beginning with Henry Johnstone's arguments, the opening lecture teases out why rhetoric should be understood more broadly and positions upcoming lectures in the realm of scholars' rhetorical thoughts both ancient and present.
\end{abstract}

Keywords: emotions, persuasion, ancient philosophy

\section{Résumé}

Cette série de cours débute par des commentaires généraux sur la rhétorique, les questions rhétoriques, les problèmes moraux, et le rapport entre émotion et persuasion. Elle offre en outre le compte rendu détaillé d'un article par Henry Johnstone afin d'y relever plusieurs questions philosophiques intéressantes reliées aux études contemporaines en rhétorique. Ce cours, bien qu'il ne soulève pas exactement les mêmes mystères métaphysiques qui ont rendu Johnstone perplexe, nous entraîne dans l'univers de la philosophie antique.

Mots clés : émotions, persuasion, philosophie antique

\section{Preface}

This lecture series began with some general comments about rhetoric, rhetorical questions, moral problems, and issues relating to the connection between emotions and persuasion. I also offered a detailed overview of an article by Henry Johnstone (2007) in order to show how there are several interesting philosophical questions related to contemporary studies in rhetoric. This lecture, while not exactly picking up on the same set of metaphysical puzzles that perplexed Johnstone, nonetheless takes us into the world of ancient philosophy.
McCarron, Gary. (2021). The McCarron Lectures. Lecture 2: The Presocratics. Scholarly and Research Communication, 12(1), 20 pp. doi:10.22230/src.2021v12n1a365
Gary McCarron is Associate Professor in the School of Communication at Simon Fraser University. Email: gmccarro@sfu.ca

* Please see Editorial: Syntheses, Reflections, and Conjectures in Scholarly and Research Communication: SRC $^{1+1}$.

* These lectures are provided with the understanding that when used in class you consider fair use, providing a payment of $\$ 10$ per student. These funds will be forwarded to the author. Please contact Marilyn Bittman, Managing Editor, SRC, for further payment information: bittmanme @shaw.ca 


\section{Scholarly and Research}

\section{Communication}

VOLUME 12 / ISSUE 1 / 2021
First, I am going to briefly discuss one of the canonical works of the Western intellectual tradition, Homer's (2018) Odyssey. This will not be an elaborate analysis of Homer's epic, which, in most translations, runs to over 550 pages. Instead, I just want to touch on a few points concerning the Odyssey that help to inform a number of the things I will say about the Presocratic philosophers, the central concern of this lecture. The Presocratics came before Socrates-in some cases by as much as two hundred years-though some were virtually contemporaneous with Socrates, a point I will come back to a bit later. Generally speaking, though, we can think of the Presocratic philosophers as prior to the fifth century BCE, the time of the major philosophical thinkers we will examine in the next lecture, Plato and Socrates. First, however, I want to talk a little about the Odyssey and the notion of Homeric rhetoric.

\section{HOMER AND RHETORIC}

Homer and Hesiod were the two great ancient Greek poets; they both lived in 700-800 BCE, approximately 400 years before Socrates. Their poetic works significantly influenced the Socratic tradition, and despite being epic narratives in the style of mythical adventures, they were understandably steeped in the cultural and philosophical world of their authors. For instance, the theme of order is prominent in their works, the idea of the cosmos as a tightly regulated and highly organized work of grandeur set on its course by the most powerful of the Greek gods, Zeus. And this sense of order, balance, and harmony would become a central concern in a great deal of Greek philosophical thinking influencing ideas about politics, the state, and ethics. What makes this concern with order relevant here is that order is possible only to the extent that chaos is contained and controlled, a point that clearly resonates with the way Johnstone (2007) describes "perfect" communication. A later lecture will touch on the importance of the concept of order in the work of the rhetorical scholar Kenneth Buke. ${ }^{1}$ For Homer and for Hesiod, order is a dynamic process, a necessary and never-ending process of containment against the problem of disorder. In the ancient Greek context, chaos is an ever-present danger in the cosmos-as the figure of Dionysus, the god of wine, dancing, and sex, makes clear. Thus, order must constantly deal with the threatening intrusions of chaos to keep the cosmos from disintegrating into meaninglessness.

In the Homeric world, order was a key principle upon which stability and moral rectitude are based, and thus the epics of Homer, Iliad (Homer, 1990) and Odyssey (Homer, 2018), speak of the need to respect the boundaries by which Zeus has organized and maintains the cosmos. This means that humans must preserve order by accepting our mortal nature and resisting the temptation to imagine ourselves as equal to the gods. Only when we refuse the seduction of hubris-excessive pride-and accept our place in the universe can we say that we have resigned ourselves to fate and that we are acting on rational motives. ${ }^{2}$ There is order in the cosmos owing to the gods, and when humans have the audacity to try to upset things, punishment is rained down upon the race of mortals, for the gods will tolerate no disobedience. Such acts of insubordination represent a refusal to accept the orderly nature of the cosmos as Zeus has decreed.

In addition to the concept of order, we can note further rhetorical issues at work in these ancient poems, especially in terms of the use of persuasive discourse. A surprising amount of Homer's Odyssey and Iliad is conveyed in speech-and quite often in the 
form of manifestly persuasive speech. One analysis suggests that as much as forty-five percent of the Iliad is in the form of direct speeches (see Pernot, 2005). Indeed, among many notable Greeks who came generations after Homer-the playwright Aristophanes, the philosopher Antisthenes, and the historian Xenophon-a view emerged declaring "Homeric rhetoric" as the ultimate source of all later theories of artful discourse. ${ }^{3}$ This declaration probably owed in part to the way the ancient sages, including figures as eminent as Plato and Aristotle, venerated Homer as among the greatest thinkers the world had known. For many Athenians of the classical period, Homer was an unparalleled model of wisdom, and the Iliad and the Odyssey were regarded as unsurpassable poetic accomplishments. Thus, it was a small step to the further claim that in these canonical works, Homer was providing a template for the rhetorical theories that would follow centuries later. These claims were further supported by the fact that persuasive language played a central a role in the narrative of the Odyssey (Homer, 2018). Throughout that epic, Odysseus' words frequently "took wings and flew" (Book 13, line 253), his eloquence a decisive element in many of his heroic exploits. For instance, when the enchantress Circe turns his men into pigs, it is through his considerable persuasive abilities that Odysseus manages to convince her to return his crew to their human form.

While cleverness in speech is one of Odysseus' most impressive qualities, the cunning he displays in the course of his ten years of adventure is joined with his equally impressive skill at deceit, trickery, and duplicity. This is not entirely surprising, of course, since verbal skill can be easily aligned with deviousness. Odysseus is an extraordinary orator, but he is far from perfect, a fact that Homer makes clear in the epic's proem. In the opening lines, Homer describes Odysseus as polytropos, from poly, meaning many, and tropos, meaning turning. ${ }^{4}$ Odysseus twists and turns throughout the adventures of the Odyssey, constantly weighing up whether he should choose honesty or deceit to deal with whatever difficulty he faces. It makes for an exciting tale as he avoids death in the Trojan war, escapes several raging storms sent by Poseidon, and uses trickery to evade the angry one-eyed Cyclopes. What is most notable for our purposes, though, is that his ability to persevere against these many catastrophes is often directly connected to his skill at persuasion. It is easy to see why Homer's (2018) Odyssey could be understood as a narrativization of rhetorical theory.

There is much to say about the rhetorical activities of the gods in respect to their relations with the human race, but I will leave the pantheon of ancient deities and now turn my attention to the Presocratic philosophers. Our discussion of the Presocratic writers will give some valuable context to the more focused treatment of Greek thought related to rhetoric in the following lecture: the critique of rhetorical ideas as advanced by Plato and Socrates.

\section{Introduction}

The usual starting point for lectures on rhetoric is the Greek philosophers: Socrates, Plato, and Aristotle. However, I am going to wander slightly off that traditional path and offer a brief overview of the work of some of the philosophers who came before Socrates, a diverse group known as the Presocratics. While Socrates is justifiably regarded as the founder of Western philosophy-and an important figure in the study

McCarron, Gary. (2021). The McCarron Lecures. Lecture 2: The Presocratics. Scholarly and Research Communication, 12(1). doi:10.22230/src.2021v12n1a365 
Scholarly and Research Communication

VOLUME 12 / ISSUE 1 / 2021 of rhetoric, too-the thinkers who preceded him were valuable in shaping the intellectual climate into which he was born; therefore, knowing something about the Presocratic tradition will prove helpful in understanding the reasons for the approach to rhetoric that Socrates ultimately followed. There is also an important debate that shaped Plato's views on rhetoric, which also originated in the ruminations carried out by the Presocratics.

First, I will discuss the history of the Presocratics in general terms, presenting some of their main preoccupations and offering an overview of the general themes they took up. Second, I will consider the ideas of two of the earliest Presocratic philosophers, Thales and Anaximander. Then, I will offer a brief summation of the key points to set up the discussion of Socrates and Plato in the following lecture.

Most of the Presocratics said rather little about rhetoric, it is true, but we will gain a better understanding of the way that Socrates formulated his ideas about rhetoric by considering certain philosophical views that emerged in the years prior to his arrival on the scene. But there are several ways in which rhetorical thought figures into the work of the Presocratics that are not explicitly given in their various theories but are apparent in the mode of their presentation.

\section{Who were the Presocratics?}

We use the term Presocratics to refer to those Greek philosophers who, for the most part, came before Socrates. ${ }^{5}$ If the term is taken too literally, however, it can imply a direct line of influence that history does not support, for not every philosopher who lived before Socrates had a visibly recognizable influence on him. Obviously, I do not mean that the Presocratics had absolutely no influence on Socrates, only that their influence was attenuated by cultural, historical, and religious factors. For one thing, the kinds of problems the Presocratics investigated differed from many of the subjects that interested Socrates, their concerns being a blend of the scientific and the philosophic. In addition, while Socrates himself recognized their influence, he could sometimes be dismissive of their accomplishments, an attitude that crops up from time to time in the Platonic dialogues. For instance, while defending himself before the Athenian court against charges of impiety in the dialogue called The Apology (Plato, 1997a), Socrates claims that his accuser, Meletus, is confusing him with the Presocratic philosopher Anaxagoras. Then, having noted the mistake he says Meletus has made, Socrates is quick to describe Anaxagoras's theories not only as different from his own but also as "absurd" (26e). Hence, it is clear in The Apology that Socrates is aware that his own position regarding piety has certain points in common with those of Anaxagoras-in fact, in other dialogues he more or less accepts that Anaxagoras had some positive influence on him. However, he generally regards the differences between their respective theories as considerable, which is partly why he criticizes Anaxagoras as having held "absurd" opinions. Still, the fact that Socrates disputed various Presocratic opinions in the Dialogues shows that their views enjoyed sufficient currency in fifth-century BCE Athens to make the task of refuting them worth the effort. Whether he was endorsing or criticizing a Presocratic idea, in other words, Socrates understood that Presocratic philosophy was important in the development of his own philosophy.

McCarron, Gary. (2021). The McCarron Lecures. Lecture 2: The Presocratics. Scholarly and Research Communication, 12(1). doi:10.22230/src.2021v12n1a365 
However, when we speak of the ideas developed by the Presocratics, what sorts of ideas are we talking about? What philosophical positions were common to the Presocratic philos-

ophers? This is where things can get somewhat confusing for modern readers, for many of the ideas the Presocratics explored focused on natural phenomena rather than on the topics we understand today as properly philosophical problems. For instance, philosophy for the Presocratics often meant things such as time measurement, the mystery of lunar eclipses, and the influence of such natural events on human behaviour in accordance with early astrology. This is not all that surprising, however, when you consider that the Presocratics lived at a time when modern scientific methods and theories were unknown, and being intellectually curious meant seeking answers to the wonders of the cosmos. What made the Presocratics different from their predecessors-what made them the earliest of the Western world's philosophers-was that they tried to separate their accounts of nature from ancient stories and mythological narratives, and they tried to establish a method of investigating nature that sought out the fundamental principles governing the natural world. They wanted to make it possible to study and understand nature, in other words, without resorting to traditional myths about the gods and supernatural powers. ${ }^{6}$

As the Presocratics lived in a mythopoeic world - that is, a world filled with tales of the gods, nymphs, giants, monsters, and courageous heroes-it would have been difficult for them to separate their ideas entirely from prevailing supernatural notions. Hence, some Presocratic theories about nature and the origins of the universe were tinged with the idealism and abstractions of then-current mythologies.7 Moreover, their theories frequently lack the rigour we associate with later philosophers, and in the absence of a disinterested empirical method, their opinions can seem more arbitrary than deductive. Indeed, this fact was not lost on some of their successors, including Socrates and Aristotle, both of whom disparaged various Presocratic philosophers for lacking a sufficiently critical attitude. So, although there is a clear line of influence from the Presocratics to Socrates, this does not mean that Socrates accepted everything they argued. That their thinking lacked the methodological force of Plato's dialectical approach or had none of the rigour of Aristotle's system of categorization, means that they were important though somewhat undisciplined thinkers.

The key question, then, is what made the Presocratics important if their theories lacked the qualified scrupulousness of later philosophy? The answer is that the Presocratics were important for their willingness to ask so-called ultimate questions-that is, questions about the why of things. They helped to make the inquiry of such enigmas as the nature of the universe potentially knowable, though today, quite frankly, their ideas seem naïve, and we would be hard-pressed to endorse any of their conclusions. But although being willing to ask why might seem like a modest accomplishment, it is important to note that philosophical topics are often defined by the sorts of questions people ask rather than by the specific answers that are given. ${ }^{8}$ Questioning is important. Therefore, it is significant that the Presocratics were certainly among the very first to ask the ultimate philosophical questions: What is the nature of the universe? Why are things the way that they are?

In contrast to the Presocratics, Socrates preferred a philosophical approach that was less concerned with understanding the nature of material things (including nature itself) and that focused on questions that dealt with people and society. ${ }^{9}$ This does not mean that his
VOLUME 12 / ISSUE 1 / 2021 


\section{Scholarly and Research}

\section{Communication}

VOLUME 12 / ISSUE 1 / 2021 views about nature and the natural world were arrived at independently of the Presocratics, for he shared their interest in cosmological problems. It is simply that he mainly devoted his philosophical inquiries to questions that put humans rather than nature at the centre. While the Presocratics were concerned with ontological matters, such as the nature of the universe and whether there is a fundamental element out of which everything is composed, Socrates was interested in philosophical questions that modern readers would be more familiar with: Is it ever right to tell a lie? Can we really understand the meaning of justice? And, the most famous of all his questions, how should one live? ${ }^{10}$

\section{What did they write?}

The preservation of texts from so long ago is often the result of accidents and good fortune. In the case of the Presocratics, we have been less than fortunate; we have very little of their original writings, and what we do possess is mainly fragments. For instance, we have only a single sentence from a book by one of the most important Presocratic philosophers, Anaximander. In fact, the author of a recent and well-known volume on the Presocratic philosophers says that so much of our information about them is incomplete that we have far more material written about the Presocratics than texts written by them (Waterfield, 2000).

In addition to the scraps of writings left by the Presocratics, though, we are lucky to have secondary commentary about their work from other philosophers and ancient historians; most of the work about the Presocratics that dates to the ancient world is in the form of secondary sources. As I have mentioned, Plato talks about various Presocratic philosophers in several of his dialogues, though his tone is not always entirely respectful. He sometimes reviews ideas with apparent approval, but at other times he mentions them with the intention of showing how old-fashioned they wereand how advanced his philosophical thinking was by comparison. ${ }^{11}$ Aristotle was more sympathetic than Socrates and Plato. He sometimes reviews specific Presocratic ideas in the same way modern scholars survey the existing literature in a field before moving ahead to establish their own theories. This is particularly apparent in Metaphysics, where Aristotle (2001) praises the Presocratic philosopher Anaxagoras, saying that he "seemed like a sober man in contrast with the random talk of his predecessors" (984b) further describing him as a person who was "somewhat modern in his views" (989b). These comments, though certainly indicating respect, are not entirely complimentary, for Aristotle praised Anaxagoras only to the extent that he believed that some of Anaxagoras' ideas anticipated views he later came to hold. So, although he is more serious than Plato in his regard for the Presocratics, Aristotle tended to regard them as having set off down the wrong pathway to truth.

We also have evidence that the philosopher Theophrastus, the man who took over Aristotle's academy upon the latter's death, wrote extensively about the Presocratic tradition, likely consulting many of the original texts that would have been available to him. ${ }^{12}$ It is even thought that he wrote complete books on certain Presocratics, but none of these texts have survived. Based on sources that drew from Theophrastus, however, it is believed that his interpretations, though thorough in terms of their scholarly detail, lacked historical objectivity. This is unsurprising, for Theophrastus was devoted to Aristotle. As a strong advocate of Aristotelianism, Theophrastus was con- 
cerned with ensuring that his famous teacher was presented as the preeminent Greek. Hence, his treatment of the Presocratics would understandably be biased.

It would be reasonable to suppose that we have, at best, a distorted and incomplete picture of the Presocratics, and that the fragments and secondary commentary we possess does not allow us much insight into their worldview. This would be an understandable conclusion, but it is not entirely correct. Despite the many difficulties determining exactly what the Presocratics argued, it is not true that we have absolutely nothing reliable to fall back on. Historians, classicists, philosophers, and Hellenic scholars have pieced together the fragments in our possession, and from those secondary sources, we can consult with an appropriately adjusted sensibility, a portrait of the Presocratics that allows us to make some general statements about them with reasonable confidence. Our knowledge of the drawbacks and problems that attend the texts we have in our possession enables us to make the allowances that are necessary to achieve a realistically objective picture of the Presocratic tradition.

\section{Who were they? Where did they live? Why did they become philosophers?}

The Presocratics, who flourished in the sixth and fifth centuries BCE, lived in Greece, of course, but they were actually scattered across the ancient world, for many also lived in those parts of the world we now know as Turkey and Italy. Although they are sometimes ignored in accounts of the history of Western philosophy, they are among the first people to have taken seriously the importance of philosophical investigation by questioning our basic assumptions about the world. The German philosopher Friedrich Nietzsche (1844-1900), who was no fan of Plato or Socrates, argued that the Presocratics invented philosophy. Indeed, Nietzsche also recognized the Presocratics as the inventors of science, a claim that shows how closely entwined philosophy and science were in the ancient world. Indeed, we sometimes refer to intellectuals of that era as natural philosophers to indicate the closeness of that connection.

Most historians of philosophy place the starting point of the Presocratic tradition in Miletus, one of the Ionian city states in Asia Minor in what is now Turkey. Miletus was located along a trade route frequented by merchants from places that included Babylon, Egypt, Lydia, and Phoenicia. As the people who followed this trade route came from diverse cities and cultures, they naturally had ideas about the world that differed from those embraced by the local Milesians. In consequence of being exposed to so many different views concerning religion, nature, astronomy, and so on, the Milesians became skeptical that every one of these accounts could be true. After all, if the Phoenicians had certain beliefs about the gods, and the Babylonians believed something entirely different concerning the divine, how could one say for certain which of the theories was correct? And the corollary to this question was even more important: If it was not possible to determine whether one or the other accounts of the gods was the right one, then who was to say that the Milesians' own account of the gods was true? If you are going to be skeptical as to the truth of competing theories, should you not include your own theory among those about which you are going to be skeptical?

Learning that there were different theories about the fundamental nature of the cosmos-and hearing different stories regarding the human place in that universe-the

McCarron, Gary. (2021). The McCarron Lecures. Lecture 2: The Presocratics. Scholarly and Research Communication, 12(1). doi:10.22230/src.2021v12n1a365 


\section{Scholarly and Research}

\section{Communication}

VOLUME 12 / ISSUE 1 / 2021
Milesians developed a cynical attitude about the actual truth value of mythological stories. Hence the Milesians regarded skepticism as the appropriate response to essential matters such as the origins of heaven and earth. They did not doubt that the merchants and other travellers with whom they came into contact believed that the myths they followed were true, but as the people who passed through Miletus were committed to such different mythologies, the Milesians were inclined to doubt that the relation between truth and belief was all that clear. Just because you believe something fervently is no guarantee that it must be true. ${ }^{13}$ Truth should be universally applicable and come from a single source, not from mythological stories that are only believed by people raised in the societies where such stories were told. Thus, a form of practical skepticism seemed the best approach for dealing with the many contradictory beliefs the Milesians encountered. ${ }^{14}$

In addition to the Milesians' exposure to the theories, philosophies, theologies, and cosmologies told by the merchants and travellers that they met as these strangers passed through their city, another important factor helped to explain the rise of philosophical investigation in Miletus: geography. Miletus was a relatively stable and prosperous city state owing to its location along an important trade route. The wealth generated by trade enabled the development of a leisure class, a class of people who had time for study and speculation. As the writer, Ellen Rose (2013) has pointed out, reflection is one of the privileges of the educated, and it is often in the process of reflecting that important philosophical insights are gained. In fact, Aristotle claimed that the main reason the Milesians developed philosophy at all was because they enjoyed sufficient spare time to devote to thinking. Time for reflection allowed the Milesians to break free of the constraints of tradition and to question the wisdom that others were more inclined to blindly accept.

In consequence of these considerations, the Milesians approached philosophy as a kind of corrective to the religious and mythological thinking that dominated the study of humans and nature at that time. They saw that it was impossible for the Egyptians, the Phoenicians, and the Babylonians to all be correct concerning the role of divine powers. The fact that their neighbours' views lacked harmony and were often in utter contradiction made this plain. Not only were the mythologies likely to be clever fiction, then, but so too the idea of the gods behind those stories might be equally fanciful. Perhaps the idea of the divine was as much a cultural phenomenon as the poetry and mythologies of the different societies the Milesians encountered.

This is a particularly important point, for the Milesians noted that the gods played a central role in most of the theories they encountered concerning the nature and origins of the universe. This was a constant theme across the many narratives the Milesians heard from the merchants passing through, but the important role given to divine powers constituted a significant problem for the Milesian Presocratics: if the gods were a decisive aspect of traditional cosmologies, and if the different theories of the gods the Milesians encountered were not in agreement, did it make good sense to allow the gods so important a role in one's theory of nature? One of the essential problems, as the Milesians saw it, was that the gods (or deities) could be terribly impulsive, and that the search for a common point of understanding would be difficult because so many religions conflicted. In addition, the gods were frequently described in different theologies as tending 
to act on motives such as anger and jealousy, and to base our understanding of nature on the unpredictable emotions of the deities-however powerful they might beseemed a risky venture. We trust the sun to rise each morning, but if we had to hope that Helios would be bringing his chariot across the horizon only on those days when he was feeling generous, then belief in the orderliness of nature would rest on terribly uncertain foundations. If one was to decide to accept the theories about the natural world proclaimed by one of the societies with which the Milesians had regular contact, then, this would also mean having to accept the truth of that society's religion, for the two belief systems, cosmology and theology, tended to go hand in hand. ${ }^{15}$ To accept the essential principles of Babylonian cosmology, for instance, you also had to accept the basic doctrines of Babylonian religion. For the Milesians, this connection was problematic.

So, the Milesians came to the position that because theological or mythical accounts of the origins of the universe differed from place to place, no one religion or mythology could claim to be universally true. Even though religions tend to preach the universality of their doctrines, the Milesians recognized that religious beliefs were local, not universal at all. Although believers imagine that their theology transcends geographical and cultural boundaries, the Milesians suspected that religions were simply parochial expressions of the human quest to find explanations. This sentiment was famously expressed by the Ionian Presocratic Xenophanes, who argued that the gods are merely reflections of ourselves and our human aspirations. In a celebrated passage, Xenophanes wrote:

If cattle or horses or lions had hands, or were able to draw with their hands and do the works that men can do, horses would draw the form of the gods like horses, and cattle like cattle, and they would make their bodies such as they each had themselves. (Kirk, Raven, \& Schofield, 2007, p. 169)

In saying that horses would draw gods that looked like horses, and cattle would draw gods that looked like cattle, Xenophanes expressed the idea, common to the Milesian intellectual class, that religious beliefs are products of the human imagination rather than divinely ordained truths delivered from on high. Hence, Xenophanes entirely rejected the role of the gods as they pertained to our understanding of the nature of the universe. Humans create human gods, and horses would create equine gods. No universal truth can be based on myth, religion, or supernaturalism.

While these ideas likely sound both secular and modern, the rejection of divine intervention confronted the Milesians with an interesting problem. Once you reject supernaturalism as the ultimate explanation, where do you turn? If there is no Zeus to bring order to the cosmos, no Poseidon to send the wind, how is nature to be understood? All theorizing must be rooted in some basic premise or foundational principle. And because the Milesians rejected theology as an acceptable foundation, they needed to formulate a principle that did not depend on a supernatural belief system. They might have felt they were being wise in dispensing with the deities in devising a theory about the origins and nature of the universe, but they still needed to find a fundamental truth to base their speculations on. If the gods played no role in accounting for nature, what or who did?

The Milesian solution was bold and simple: rather than try to create yet another mythological story, they chose to rely on the world itself as the source of their explanations. In

McCarron, Gary. (2021). The McCarron Lecures. Lecture 2: The Presocratics. Scholarly and Research Communication, 12(1). doi:10.22230/src.2021v12n1a365
VOLUME 12 / ISSUE 1 / 2021 


\section{Scholarly and Research} Communication

VOLUME 12 / ISSUE 1 / 2021 other words-and here you can see why Nietzsche saw the people of Miletus as both philosophers and scientists-they determined that the only reasonable way to explain the cosmos was based on natural principles, not supernatural principles. Natural law, in other words, would be the essential principle that explains nature. This strategy may seem obvious today, but in the context of Milesian times it was novel and quite brilliant. Realizing that religious stories about the universe are relative to the places where they were devised, the Milesians sought a foundation point that would be common to all people, at all times, and in all places, regardless of their belief system. Religious beliefs are rarely held universally, but natural explanations could be believed by anyone, no matter where they lived, for they do not require knowledge of, or belief in, a specific deity or myth. Natural explanations would be universal, because one could always test and verify a statement about a certain natural phenomenon by appealing to principles based on empirical facts; in this sense, such principles would be universal. Knowledge would no longer be dependent on one's location or even one's culture; rather, it would be the case that if something was true in Babylon, it would also be true in Miletus. One god might make water boil in one society and another god might make water boil in another society, but nature dictates that water will always boil at 100 degrees Celsius in all societies. You might say that it is much easier to believe in nature than in a number of different supernatural beings.

The notion that natural explanations would apply equally the world over was appealing as the foundation for knowledge claims, but the Presocratics of Miletus carried their program even further. In addition to universality, the Milesians also aimed for parsimony; that is, the Milesians tried to make their explanations as simple as they could. To do this, they privileged what is sometimes called the principle of reduction by narrowing down the necessary explanatory factors to as small a number as possible. ${ }^{16}$ The idea behind the principle of reduction is that when faced with different possible explanations, we should always appeal first to the simplest explanation. In other words, why invoke a god or deity when a known natural principle could do the job? It might be comforting in some way to think that divine will is behind everything, but if you could get by with an explanation that did not invoke divine purpose, would this not be preferable? If you know that fire produces heat, heat turns ice to water, and water, when subjected to heat, turns into steam, then why not investigate the properties of heat to see if it might be able to explain all sorts of natural phenomena and leave the gods out of the explanation entirely? Why multiply causes unnecessarily? Whereas mythologies rely on the whim of the notoriously unpredictable gods, the Presocratic Milesian philosophers sought out laws, principles, and processes that were independent of the will of the deities. Law-like regularity replaced divine capriciousness. By reducing their explanations as much as they could, the Presocratics discovered the idea of what is often called natural order.

Aristotle was greatly impressed by the principle of reduction and regarded his own approach to the study of nature as having been shaped by the investigatory techniques of the Milesians. In fact, Aristotle tended to divide early philosophers into two groups. The first, the theologi, were those thinkers who regarded the world as under the control of impulsive supernatural beings or gods. These were people who accepted the explanatory power of mythologies and whose accounts of the natural world were beholden to religious or supernatural principles. The second group, the group that 
Aristotle admired, he called the physici. These were the Presocratic philosophers, those who sought simpler, natural principles for explaining the universe. The Presocratics of Miletus, by Aristotle's account, were mostly physici, and it was the physici, he claimed, who set the stage for the development of true philosophy. The key to the success that the physici enjoyed, and the reason for Aristotle's admiration, is that they posited a method for investigating the world that relied first and foremost on reason and that dispensed with the presuppositions that came from traditional stories and mythology. The Milesian Presocratics, as Aristotle saw it, taught us how to think critically.

I have been speaking very generally about the Presocratics, and it will be helpful to give you a better sense of the Presocratic tradition by describing the work of two of the most preeminent Presocratics from Miletus: Thales and Anaximander. Miletus was small enough that they might have known one another, but it is not clear if they were acquainted personally, though their ideas circulated widely. Some ancient accounts refer to them as having enjoyed a teacher-pupil relationship, but this has never been established. In ancient texts, we also read that some Presocratics were thought to be related genealogically, but this was probably meant in a metaphorical sense rather than as an expression of a flesh-and-blood line of descent. It is possible that Thales and Anaximander actually knew one another, but it is not terribly important. It is their ideas about nature and philosophy that command our attention.

\section{Thales of Miletus}

Although the most famous story about Thales (pronounced THAY-lees, sometimes TAL-ees) is that he was the first person said to have correctly predicted an eclipse, most historians now believe the story is probably a fabrication. Still, it is a good story.

It is said to have occurred during a battle between the Lydians and the Medes, two neighbours of the Milesians. According to the legend, Thales predicted an eclipse would occur on a specific day at a precise time, and when the eclipse happened as he had said it would, this so impressed (and perhaps intimidated) the combatants that they threw down their weapons and made peace. The success of this prediction brought Thales to the attention of the Athenian aristocracy; it also got him noticed by various state rulers who subsequently developed considerable respect for Thales and his method of reasoning. (The ancient historian Plutarch writes that Thales was an acute political thinker, an appraisal that was likely influenced by the story of the predicted eclipse.) Today, it is thought that Thales might have been able to make a general prediction (say, in the year $585 \mathrm{BCE}$ ) because he was well-travelled, educated, and knew a good deal about astronomy, which he mainly learned from the Babylonians. Even with that information, however, his prediction-if offered in the fashion outlined in the legend—-was probably a lucky guess.

But if the story that Thales successfully predicted an eclipse is untrue, are there verifiable accomplishments that make him memorable? The answer is easy, for Thales's greatest contribution to philosophical thought was his explanation of the origins of the cosmos. Thales famously claimed that everything comes from water, but whether he meant to say that everything derives from water-that is, comes out of the water-or everything is made from water has confused philosophers and historians for generations. Perhaps he meant both, but this would raise other problems. Regardless, for his part, Aristotle

McCarron, Gary. (2021). The McCarron Lecures. Lecture 2: The Presocratics. Scholarly and Research Communication, 12(1). doi:10.22230/src.2021v12n1a365 


\section{Scholarly and Research}

\section{Communication}

VOLUME 12 / ISSUE 1 / 2021 believed that Thales meant everything is made from water, and that water is the arche, that is, the fundamental substance everything is composed of. Aristotle found this argument both amusing and unlikely, citing several reasons why it could not be accurate. Dust, for instance, cannot come from water, Aristotle said, and thus Thales was not to be taken too seriously as to this aspect of his theorizing. But while Aristotle laughed at Thales (even as he also admired his intellect), and while we might laugh at him today, his choice of water instead of earth or fire, for example, was a smart move, since water can be seen to take different forms, such as liquid, mist, hail, ice, or steam. The mutability of $\mathrm{H}_{2} \mathrm{O}$, in other words, makes it an interesting choice as the basis for the composition of the cosmos. Aristotle suspected that Thales chose water because it is associated with life: food, blood, amniotic fluid, and semen all contain water, and all plants and animals need water to survive. Moreover, it seems clear according to most historians that Thales was influenced by Babylonian and Egyptian mythology, both of which also maintained that water is a central element in the production of life. If this connection is true, then it would be an example of where a Presocratic thinker was unable to separate his ideas completely from the mythological ideas circulating about him.

But Thales was not simply recapitulating the narratives of the Babylonians and the Egyptians, for unlike the mythologists who asserted the preeminent role of water, Thales made the effort to explain his theory. These attempts admittedly led him into some rather fanciful assertions, including his suggestion that just as logs and other objects float on water, so too the earth floats on water, an idea (and an image) that literally makes water the very foundation of all things. Aristotle pointed out that this theory created additional problems, however, because if the earth floated on water, what did the water under the earth float on? Furthermore, just because logs float, does it stand to reason that the earth would float? Maybe the earth would sink? What evidence exists that the earth is buoyant? This hypothesis would be rather challenging to test in a laboratory. Just how much water would be needed, and how large a container would be required to hold that volume of water? These are obviously insuperable difficulties.

So, along with Aristotle, we can, if we so choose, ridicule the theory of water that Thales formulated. However, it is important to note that our refutation takes the essential form of a scientific rebuttal. This is significant, for the fact that we are inclined to refute his ideas is itself important, because refutations show something significant about the Milesian approach that distinguished it from the mythological approach of earlier thinkers.

As we are forced to refute Thales by arguing from facts and logic, this makes his theory quite different from traditional mythologies. The fact that we argue with Thales-that we try to refute his ideas by pointing out counterexamples such as dust-shows why he was ahead of the Egyptian and Babylonian mythologists. Whereas there is usually no point in arguing with someone who accepts the truth of a religion or a myth, you can at least argue with someone who endeavours to provide reasons for a theory that rely on natural rather than supernatural causes. The argument that one of the deities created the cosmos is irrefutable as long as the person claiming that position responds to each criticism by reasserting that the gods can do what they please. But with Thales, we at least have a 
theory (the theory of water) to discuss; moreover, we can ask whether his basic insight that there is an arche, or fundamental substance, is correct. Perhaps there is such a thing and he just got the most important detail wrong in choosing water. It is important, in other words, that Thales makes the effort to establish his ideas on the basis of known science rather than just repeating a common myth of the times. He does not have a way of really testing his theory experimentally, but he does invoke reason in trying to support his account. Of course, Thales got his theory of the cosmos wrong-just as his theory that magnets are alive was wrong too. But given that there was no theory of life in seventh century BCE, we should not hold Thales to the same standards as modern thinkers with their modern measuring equipment and devices. Keep in mind that Thales was proposing a theory, and that he was not merely proclaiming the truth of a myth or religious doctrine. His attempt to ground that theory on natural principles and logical reasoning was what made his work noteworthy. That later philosophers sought to refute him rather than ignore him shows that he earned their respect, if not their agreement.

Finally, one of the most common stories about Thales is that he once fell into a ditch while trying to observe the night sky and had to be rescued by a young slave girl who laughed at his misfortune. ${ }^{17}$ It is an anecdote that appears in virtually every account of Thales' life, making him the stereotype of the absent-minded male professor. Interestingly, when Aristophanes, the Greek comedic playwright, tells the story of the philosopher whose inattention to everyday life leads to his falling into a ditch in his play Clouds, it is Socrates who is said to have fallen into the ditch, not Thales (Socrates was not amused to find himself treated so irreverently!). However, when Plato tells the story of the stumbling philosopher in his dialogue Theaetetus, he correctly identifies the inattentive scholar as Thales. So, it would seem that if you want to ridicule philosophers and intellectuals (and maybe professors), the best strategy is to suggest that their focus on otherworldly abstractions is so all-consuming that they lose sight of the things right in front of them. This is particularly ironic since Thales endeavoured with his naturalistic theories to attend to what was right in front of him.

\section{Anaximander of Miletus}

Anaximander (pronounced ah-NAX-imander) was also a Milesian whose life is dated somewhere between 610-546 BCE, though, as with many of the Presocratics, the dates are not certain. Younger than Thales by 14 years or so, Anaximander is often described as Thales' pupil and successor-although no one really knows if they ever met, let alone studied together. Like Thales, Anaximander was a polymath, that is, someone who knew a lot about a large range of subjects. He was also well-travelled and even produced a map of the known world. He wrote a book, thought to be titled On Nature, from which only a single sentence survives. ${ }^{18}$ Anaximander was a brilliant scholar who is credited with introducing the Greeks to the sundial and devising some mathematical principles based on the gnomon, the triangular part of the sundial that throws the shadow. Among his many talents, he was a gifted mathematician.

It is said that while Anaximander knew a lot, he was not shy of making things up to cover over gaps in his knowledge. This may not be entirely fair, but it is certainly true that he was willing to speculate freely on a broad range of subjects. One of the more important topics he speculated on was the origins of different kinds of weather. These are actually

McCarron, Gary. (2021). The McCarron Lecures. Lecture 2: The Presocratics. Scholarly and Research Communication, 12(1). doi:10.22230/src.2021v12n1a365 


\section{Scholarly and Research}

\section{Communication}

VOLUME 12 / ISSUE 1 / 2021 rather amusing to read today for their fanciful speculations. But Anaximander was also devoted to close, observational studies. For instance, he devised techniques for measuring time and for determining more precise dates for solstices and equinoxes. He was also a dedicated cosmologist, writing about the origins of the stars and the relative sizes of objects in the visible sky. Given that he calculated the moon to be eighteen times the size of the earth, however, we know that his calculations were not always accurate.

What is interesting about Anaximander is in the way that he departed from Thales. Anaximander did not accept the idea that water is the arche (or the fundamental principle) of the universe, but there was something in Thales' approach to this cosmological question that Anaximander found attractive. Whereas Thales said that science should reduce everything down to basic principles, Anaximander said that the true scientist must go even further, for there is more to nature than meets the eye-literally. This something more, he said, was probably nothing. Anaximander refused to endorse water, earth, or fire as the arche, and this left him with, well, nothing. This claim obviously requires an explanation, so let me try to make something of nothing.

Thales was likely influenced by Egyptian and Babylonian creation myths, even as he tried to separate his philosophy from traditional mythology. Anaximander was more successful than Thales in rejecting mythological thought and in postulating an entirely naturalistic system. Indeed, when he turned to hypothesize about the fundamental building block of nature, he did not choose any of the known or visible substances chosen by other Presocratics - such as water or air-but said that everything is made from something that is invisible. The word he used, apeiron (appear-on), is usually translated as "the indefinite," the "unlimited," or the "indeterminate." It is also sometimes translated as "the infinite," but this might have struck Anaximander as being too supernaturalistic. What is important is that apeiron has no discernible qualities of its own. It is nothing, neither this nor that.

Whereas Thales was interested in understanding the fundamental nature of reality by determining its underlying element-which he thought was water-Anaximander was more interested in postulating the underlying principle of reality. ${ }^{19}$ For this reason, it is sometimes difficult to get a firm grasp on what Anaximander was trying to say, though his essential insight into the possibility of a fundamental principle is certainly impressive. Consider that we can only successfully uncover fundamental—or foundationalprinciples by observing the actions and/or behaviours of actual objects. Even then, however, we have to leave the objects behind at some point and figure out a way that we can observe the unobservable principle that governs them. Let me offer an example. We can watch all sorts of objects falling to the ground, but only by the use of reason-and the application of mathematics to our observations-would we ever discover the reason things fall: the principle of gravity. Gravity is an underlying principle that is essential to the nature of reality, but we do not see gravity when something falls, we only see the thing that falls, for gravity is not itself a visible thing. We can see the wind moving the leaves and even feel it in our face, but we cannot actually see the wind. We see the effects of principles rather than the principles themselves. Once Anaximander began to think about underlying principles, the theme of invisibility became important to him. His thinking was sophisticated and challenging, especially as he was determined to find the 
principle that was the foundation for all of reality, not only certain aspects of reality. You can sense why this underlying principle was invisible—or nothing.

Sophisticated though the principle of nothing may sound, it turned out to be a problem for Anaximander and his later interpreters, for although the apeiron is a modern-sounding and even tantalizing idea, it is certainly difficult speaking of "the nothing" when we are seeking to talk about something. Further, only a single sentence of Anaximander's writings has ever been recovered. Hence, we must rely on secondary sources to figure out what he meant. Fortunately, ample secondary sources written by people familiar with his work make it possible to piece together a reasonable picture of his arguments.

One certainty about Anaximander is that he claimed that all observable things tend to appear before us in opposites: hot and cold, young and old, wet and dry, light and dark, and so on. He also said these elements (which is what he called them) seem often to be in a state of war. The idea of a war between hot and cold probably sounds peculiar, and for that reason I think this would be a good time to quote Anaximander's single, surviving sentence. Here is that sentence-so far as we can determine-as it is given to us by the fifth-century BCE Neoplatonist Simplicius.

And the source of coming-to-be for existing things is that into which destruction, too, happens, "according to necessity; for they pay penalty and retribution to each other for their injustice according to the assessment of time." (Kirk et al., 2007, pp. 117-118)

I wonder if this is all that helpful in our efforts to understand Anaximander! However, if we take it apart slowly and apply what we know about Anaximander from other sources, it translates into something like the following.

Opposites approach one another in a state of conflict (say hot and cold, for instance) because, in a very simple sense, they are opposed to one another at a basic, experiential level. The "conflict," in other words, is just that they are essentially opposed to one another as logical opposites. For instance, we use heat to banish the cold when we are chilly, and we seek a cool lake on a hot day. Nothing is more un-cold than hot, and nothing is more un-hot than cold. So, things that are hot, one might say, are the opposite of things that feel cold, and for this reason we can say that they approach one another in a state of conflict. Moreover, you can "banish" the cold by introducing heat, and you can also "banish" heat by subjecting it to something cold. So, the idea that things that are opposite can be described as being "at war" makes sense. Second, these opposing things encroach on one another inasmuch as they come into contact when, for example, warm and cold weather systems collide, or when heat is applied to cold food, or when rain falls on parched ground. In the passage cited above from Simplicius, this is described as the idea of opposites committing injustice on one another-heat, for instance, commits an injustice on cold by driving the cold away. These opposites thus pay a penalty in the sense that one or the other is "victorious," and retribution is meted out as first one and then the other becomes dominant with time serving as the referee ("according to the assessment of time"), for the victory of one is usually temporary. Things that are very cold will eventually warm up, whereas very hot things will eventually cool down. Everything we see around us, then, is a process of opposites coming into contact, waging

McCarron, Gary. (2021). The McCarron Lecures. Lecture 2: The Presocratics. Scholarly and Research Communication, 12(1). doi:10.22230/src.2021v12n1a365 


\section{Scholarly and Research}

\section{Communication}

VOLUME 12 / ISSUE 1 / 2021 their war, achieving a temporary victory, and then returning to the previous state. Thus this "war" results in continuous change. Let us try another example.

Light and dark are in conflict because they are opposites, and time decrees that first one and then the other should be the victor. No sooner has darkness (or night) won its victory, than daylight fights back: the sun rises and light assumes the dominant position. The conflict is largely metaphoric, though it does express the idea that for darkness to come into ascendancy, for example, light must be defeated. Similarly, youth must give way to age, and the aged must die while new babies are born. The conflict is not entirely antagonistic, then, so much as it is part of the fabric of everyday existence. Hence, Anaximander says that all of this happens "according to necessity," a philosophical way of stating that this is simply the way the universe is organized. After all, the ancient Greeks did have a fascination with the orderliness of the cosmos. Hence, day turning into night and night turning into day is not haphazard or accidental; it is necessary. The conflict of opposites is the way the cosmos is structured..$^{20}$

The idea that the universal principle, or arche, the apeiron, is really conflict has been enormously influential. It makes untold appearances in Western literature and certainly has its place in sociology, where you can find several so-called conflict theories that purport to explain the rise of civilization and the movements of cultural history as the products of various kinds of conflict. ${ }^{21}$ In this regard, Anaximander's views are indeed somewhat modern. His idea is that all the elements are composed of oppositions held together in dynamic tension, and that we see them separated out from one another-as when day turns to dark and vice versa. Moreover, this process does not involve actual destruction, which is why some commentators referred to the apeiron as the infinite. In other words, the separation of opposites is indeed only a separation, and nothing is ever destroyedthe two things remain. Light is not destroyed even when vanquished by night, and night is not destroyed by the arrival of the dawn; both will return "according to necessity" as determined by "the assessment of time." Through a process of settling out (separation) that occurs because of the way time permits the periodic transformation of one condition into its opposite, everything is ultimately preserved. Light and dark are united in the apeiron, but their settling out (or separation) is dictated by natural law. ${ }^{22}$

Anaximander said his theory answered a question that Thales and others had not even considered: the problem of transformation. If everything comes from water, as Thales argued, then how would fire, for instance, ever appear? Thales might have been stumped by this question, but Anaximander was ready with a response, arguing that both water and fire are produced in the original apeiron in which the elements are already apparent in their relationship of perpetual conflict. Indeed, once he hit on the basic notion of the apeiron, Anaximander suggested other scientific propositions were now proven. He claimed that the cosmos-the entire universe-was born from a separation of the hot and cold elements-the cold became the earth, for instance, and the hot became the sun and the stars - a very early example, some have claimed, of the big bang theory. Anaximander also debunked the idea that the earth rests on anything, let alone a cushion of water as Thales proclaimed. Instead, he said the universe is spherical, and the earth rests at the centre with everything circling around it. This is why the earth cannot fall, because it is at the centre and held in place by forces of equilibrium,

McCarron, Gary. (2021). The McCarron Lecures. Lecture 2: The Presocratics. Scholarly and Research Communication, 12(1). doi:10.22230/src.2021v12n1a365 
or what Anaximander called equality. Of course, while the insight is clever and hints at a rather early conception of gravitational force, this proposition is ultimately wrong. However, compared to his fellow Presocratics, Anaximander's apeiron is certainly a sophisticated notion.

Most important, the apeiron is entirely non-mythological insofar as Anaximander supplanted the supposed will of the gods with the impersonal forces of nature. According to Anaximander, the cosmos is an orderly system regulated by natural laws that can be understood by the application of reason. Hence his views stood in contrast to the mythological world of many of his predecessors and contemporaries who remained committed to the chaotic and fickle desires of the gods. His ideas were, in many ways, the most sophisticated of the Milesian philosophers and certainly among the most abstract.

\section{Conclusion}

There were other important Presocratics, too many to discuss here. Indeed, I have only tried to give you a sense of the historical context in which they worked (or did not work, as Aristotle suggested, since he imagined them just sitting around thinking). I have offered two of the Presocratics as examples of the kinds of issues they dealt with and the nature of their conclusions. In the lecture on Plato, I will return to the Presocraticsthough only very briefly - with a discussion of two other famous Presocratics, Heraclitus and Parmenides. They were philosophers whose differing positions on some of the issues raised here played a decisive role in Plato's views of rhetoric.

The Presocratics tended toward investigations that contemporary readers may find difficult to connect to current philosophical interests. But as is the case with all thinkers, we must consider the time in which they lived and the cultural concerns that motivated their reflections. "When we consider the grotesqueness of some of the mythological background from which the pre-Socratic thinkers started," writes William Guthrie (1967), "we must be amazed by the intellectual insight and firm grasp of universal principles which at their best they were capable of displaying." High praise indeed.

However, at the same time, Guthrie adds,

a dispassionate assessment of their contribution to the history of philosophy would probably show that, to use a metaphor, although they manufactured many of the pieces and set them on the board, Plato and Aristotle were the first players who learned the rules and started the game. (p. 455)

In Lecture 3, we will enter that game and see what Plato and Aristotle made of the pieces the Presocratics set on the board and how they devised the rules to govern the movement of those pieces. How did the subject of rhetoric develop following the Presocratics' initial adventures in philosophical deliberation?

\section{Notes}

1. Douglas Thomas (1993) has an excellent account of Burke's ideas concerning the relationship between order and rhetoric.

2. Hubris, or the overweening pride to see oneself as a god, is a temptation many mortals and heroes in Greek literature found hard to resist. In other words, the 


\section{Scholarly and Research}

\section{Communication}

VOLUME 12 / ISSUE 1 / 2021 seduction of power and the yearning for immorality were often at the root of human misadventures-much as Adam and Eve were unable to resist the seductions of Satan, and the power they thought would come from eating the fruit of the tree of knowledge.

3. Most histories of rhetoric pass over the influence of Homer on rhetoric or mention it only in passing. However, a recent work by Rachel Knudson (2014) argues that the influence of Homer was far more significant than has been conventionally imagined. She suggests the strong possibility, for instance, that Aristotle's rhetorical theories were actually drawn from his own studies of Homer.

4. Daniel Mendelsohn (2017) translates this word for English readers as twisty, while Emily Wilson (2018) renders the word as complicated. Both apply to Odysseus rather well. In English, ploytropos appears in the flower known as heliotrope, a plant that turns (trope) toward the sun (Helios). In fact, tropic also comes from tropos, as it is where the sun appears to turn from north to south.

5. Why do I say that "for the most part" the Presocratics came before Socrates? Because not all of them were pre-Socrates in a strictly historical sense. For example, Anaxagoras, one of the more prominent Presocratics, was born around $500 \mathrm{BCE}$, whereas Socrates was born in approximately $470 \mathrm{BCE}$, so their lives partially overlapped. What, then, makes Anaxagoras a pre-Socratic? The answer historians offer is that the term Presocratic has two meanings. First, we name as Presocratics those writers who came before Socrates; we can call them chronological Presocratics. Second, other philosophers are referred to as Presocratics not because they came before Socrates (they might have been contemporaries) but because the philosophy they practiced was in keeping with the interests and approaches of those philosophers who lived in the centuries and decades before Socrates. These might be called thematic Presocratics. So, Anaxagoras, for instance, is called a Presocratic because he shared many of the natural philosophy interests of the chronological Presocratics, despite being a contemporary of Socrates. It hardly needs pointing out that the term Presocratic is an inelegant solution to this problem, but because most of the Presocratics indeed lived and died before Socrates arrived on the scene, it is the solution historians have chosen.

6. In his classic work Psyche: The Cult of Soul and Belief in Immortality Among Ancient Greeks, Erwin Rohde (1925) says that the Presocratics pursued philosophy "unhampered by any subservience to mythical or religious modes of thought" (p. 362). Strictly speaking, this is not entirely true, though it captures well the point I have just made.

7. A wonderful book that treats this aspect of the Presocratic tradition is Kathryn Morgan's (2000) Myth and Philosophy from the Presocratics to Plato.

8. "Every age in the history of philosophy has its own preoccupation," philosopher Susanne Langer (1942) says, adding that "it is the mode of handling problems, rather than what they are about, that assigns them to an age.... The way a question is asked limits and disposes the ways in which any answer to it — right or wrong - may be given.... Therefore, a philosophy is characterized more by the formulation of its problems than by its solution of them" (pp. 15-16).

9. In fact, Socrates was quite willing to rely on ancient myths when dealing with questions about nature of the origins of the cosmos. 
10. The French philosopher Luc Ferry (2010) has a wonderful book that explores the history of philosophy from the point of view of people seeking an answer to this simple question: how should one live?

11. In the dialogue Phaedo (Plato, 1997b), Socrates offers one of his most lengthy and even-handed accounts of the Presocratic tradition, though his goal is still to show the many ways in which previous philosophers mixed and muddled things up. See particularly the discussion that begins in Phaedo at section $96 \mathrm{ff}$.

12. On this argument see, for example, Peter Adamson's (2015) Philosophy in the Hellenistic \& Roman Worlds: A History of Philosophy Without any Gaps.

13. "Because someone is willing to die for what they believe," Oscar Wilde (2006) once said, "does not prove that their belief is true."

14. Paul Veyne's (1988) Did the Greeks Believe in their Myths: An Essay on the Constitutive Imagination is an exceptional book that discusses belief, truth, and myth.

15. This part of the Milesians' dilemma has not disappeared entirely, of course, as some people continue to draw connections between religion and science. Those Christians who doubt the evidence of biological evolution based on their belief that the Bible is literally true are one example.

16. The principle of reduction is still a hallmark of scientific thinking, but it is also frequently advocated as a method for clear thought in domains other than science. For instance, conspiracy theories often involve complex webs of interconnection between individuals, agencies, and institutions, when simpler, less complicated explanations that might be more efficient (and more likely) are available. This is usually referred to today as Occam's razor in recognition of William of Occam, who formulated the principle in the thirteenth century, quite some time after the idea was first proposed by the Presocratics.

17. Obviously, this story influenced the story of the flappers who keep the intellectual beings of Laputa from self-harm in Jonathan Swift's (2005) novel Gulliver's Travels.

18. It is a common tradition that books written during this period are titled On Nature.

19. I am being somewhat unfair to Thales in making this claim, for he too sought an underlying principle. His search, however, was more generic, for the principle guiding his search for the arche was to find the basis for nature's order. That is, his underlying principle explaining the cosmos was its orderliness.

20. To reiterate, the importance of the idea of things arranged "according to necessity" was to prove of enormous consequence in later Greek philosophy, as it essentially explains the orderly nature of the cosmos.

21. Marxism and other theories based on class conflict are the most obvious examples.

22. When Zeus ascends to Olympus he is forced to fight against Typhon, a great being who represents the forces of chaos. Zeus is victorious, but he does not destroy Typhon; rather, he banishes him forever to the underworld (Tartarus), where he is imprisoned for eternity. Chaos, in other words, is always present and thus we must be vigilant in our efforts to maintain order.

\section{References}

Adamson, Peter. (2015). Philosophy in the Hellenistic \& Roman worlds: A history of philosophy without any gaps (Vol. 2). Oxford, UK, \& New York, NY: Oxford University Press.

McCarron, Gary. (2021). The McCarron Lecures. Lecture 2: The Presocratics. Scholarly and Research Communication, 12(1). doi:10.22230/src.2021v12n1a365 


\section{Scholarly and Research}

\section{Communication}

VOLUME 12 / ISSUE 1 / 2021
Aristotle. (2001). Metaphysics (W.D. Ross, Trans.). In R. McKeon, The basic works of Aristotle (pp. 682-926) New York, NY: The Modern Library.

Ferry, Luc. (2010). A brief history of thought: A philosophical guide to living (T. Cuffe, Trans.). New York, NY: Harper Perennial.

Guthrie, William K.C. (1967). Pre-socratic philosophy. In P. Edwards (Ed.), The encyclopaedia of philosophy (Vol. 6) (pp. 441-446). New York, NY, \& London, UK: MacMillan.

Homer. (1990). Iliad (R. Fagles, Trans.). Harmondsworth, UK: Penguin Books.

Homer. (2018). Odyssey (E. Wilson, Trans.). New York, NY, \& London, UK: W.W. Norton \& Company. Johnstone, Henry. (2007).The philosophical basis of rhetoric. Philosophy and Phetoric, 40(1), 15-26.

Kirk, Geoffrey S., Raven, John E., \& Schofield, Malcolm. (2007). The presocratic philosophers (2nd ed.). Cambridge, UK: Cambridge University Press.

Knudson, Rachel Ahern. (2014). Homeric speech and the origins of rhetoric. Baltimore, MD: Johns Hopkins University Press.

Langer, Susanne K. (1942). Philosophy in a new key: A study in the symbolism of reason, rite and art. New York, NY: Mentor Books.

Mendelsohn, Daniel. (2017). An odyssey: A father, a son, and an epic. New York, NY: Vintage Books.

Morgan, Kathryn. (2000). Myth and philosophy from the Presocratics to Plato. Cambridge, UK, \& New York, NY: Cambridge University Press.

Pernot, Laurent. (2005). Rhetoric in antiquity (W.E. Higgins, Trans.). Washington, DC: The Catholic University Press.

Plato. (1997a). The apology (G.M.A. Grube, Trans.). In J.M. Cooper (Eds.), Plato: Complete works. Indianapolis, IN, \& Cambridge, MA: Hackett Publishing Company, 1997.

Plato. (1997b). Phaedo. (G.M. Grube, Trans.). In J.M. Cooper (Ed.), Plato: Complete works (pp. 49-100). Indianapolis, IN, \& Cambridge, MA: Hackett Publishing Company.

Rohde, Erwin. (1925). Psyche: The cult of soul and belief in immortality among ancient Greeks. Eastford, CT: Martino Fine Books.

Rose, Ellen. (2013). On reflection: An essay on technology, education, and the status of thought in the twenty-first century. Toronto, ON: Canadian Scholars Press.

Swift, Jonathan. (2005). Gulliver's travels (C. Rawson, Trans.). Oxford, UK: Oxford University Press. (Original work published 1726.)

Thomas, Douglas. (1993, August). Burke, Nietzsche, Lacan: Three perspectives on the rhetoric of order. Quarterly Journal of Speech, 79(3), 336-355.

Veyne, Paul. (1988). Did the Greeks believe in their myths: An essay on the constitutive imagination. Chicago, IL: University of Chicago Press.

Waterfield, Robin. (2000). The first philosophers: The Presocratics and sophists. Oxford, UK, \& New York, NY: Oxford University Press.

Wilde, Oscar. (2006). The portrait of Mr. W.H. In The complete short stories of Oscar Wilde (pp. 52-82). New York, NY: Dover Publications, Inc.

Wilson, Emily. (2018). The odyssey. New York, NY, \& London, UK: W.W. \& Norton. 